RESEARCH ARTICLE

\title{
Evaluation of a semi-automatic system for long-term seawater carbonate chemistry manipulation
}

\author{
Evaluación de un sistema semiautomático para la manipulación del sistema carbonato \\ en agua de mar durante periodos extensos
}

\author{
RODRIGO TORRES ${ }^{1,{ }^{*}}$, PATRICIO H. MANRIQUEZ ${ }^{2,8}$, CRISTIAN DUARTE $^{3}$, JORGE M. NAVARRO ${ }^{2}$, \\ NELSON A. LAGOS ${ }^{4}$, CRISTIAN A. VARGAS ${ }^{5} \&$ MARCO A. LARDIES 6,7
}
${ }^{1}$ Centro de Investigación en Ecosistemas de la Patagonia (CIEP), Ignacio Serrano 509, código postal 5951601, Coyhaique, Chile ${ }^{2}$ Instituto de Ciencias Marinas y Limnológicas, Laboratorio Costero de Recursos Acuáticos de Calfuco, Facultad de Ciencias, Universidad Austral de Chile, Independencia 641, código postal 5110566, Valdivia, Chile
${ }^{3}$ Departamento de Ecología y Biodiversidad, Facultad de Ecología y Recursos Naturales, Universidad Andrés Bello, República 470, Santiago, Chile
${ }^{4}$ Facultad de Ciencias, Universidad Santo Tomás, Ejército 146, Santiago, Chile
${ }^{5}$ Laboratorio de Funcionamiento de Ecosistemas Acuáticos (LAFE), Unidad de Sistemas Acuáticos,
Centro de Ciencias Ambientales EULA Chile, Universidad de Concepción, Casilla 160-C, Concepción, Chile
${ }^{6}$ Departamento de Ciencias, Facultad de Artes Liberales, Facultad de Ingeniería y Ciencias, Universidad Adolfo Ibáñez,
Diagonal Las Torres 2640, Peñalolén, Santiago, Chile
${ }^{7}$ Center for Aquaculture Research (INCAR)
${ }^{8}$ Present address: Laboratorio de Ecología y Conducta de la Ontogenia Temprana (LECOT), Centro de Estudios Avanzados en Zonas Áridas (CEAZA). Avenida Ossandón 877, Coquimbo, Chile
*Corresponding author: rtorres@ciep.cl

\begin{abstract}
The assessment of the effects of Ocean Acidification $(\mathrm{OA})$ on marine life has received increasing attention in recent marine research. On a mesocosmic scale, the $\mathrm{CO}_{2}$ levels in seawater can be manipulated to evaluate experimentally the consequences of $\mathrm{OA}$ on marine organisms (vertebrates and invertebrates). An ideal manipulation of carbonate chemistry should mimic exactly the changes to carbonate chemistry, which will occur in years to come. Although some methods have been described in the literature, here we describe in detail a simple, robust and inexpensive system to produce $\mathrm{CO}_{2}$-enriched seawater by bubbling the seawater with air- $\mathrm{CO}_{2}$ mixtures. The system uses mass flow controllers (MFC) to blend atmospheric air with pure $\mathrm{CO}_{2}$ to produce two $\mathrm{pCO}_{2}$ levels. The air- $\mathrm{CO}_{2}$ mixtures are delivered continuously to seawater equilibration reservoirs, and simultaneously to an infrared $\mathrm{CO}_{2}$ analyser to verify $\mathrm{CO}_{2}$ levels in the air- $\mathrm{CO}_{2}$ mixture delivered to the equilibration tanks. We monitored both $\mathrm{pH}$ and total alkalinity in the equilibration reservoirs over a period of one year in order to document the long-term performance of this system for simulating the future carbonate chemistry of seawater in a coastal laboratory. System performance was sufficient to maintain three contrasting (e.g., 397, 709 and 1032 matm) and relatively constant (the coefficient of variability was $11 \%$, $9 \%$ and $9 \%$ respectively) seawater $\mathrm{pCO}_{2}$ during a year-long monitoring.
\end{abstract}

Key words: carbonate chemistry manipulation, ocean acidification.

\section{RESUMEN}

La evaluación de los efectos de la acidificación oceánica en la vida marina ha recibido creciente atención en la actual investigación marina. A escala de "mesocosmos" los niveles de $\mathrm{CO}_{2}$ del agua de mar pueden ser manipulados para permitir la experimentación con organismos marinos (vertebrados e invertebrados). Una manipulación óptima de la química del carbono debiese emular exactamente los cambios esperado en la química del carbono. A pesar que algunos métodos han sido descritos en la literatura, el presente estudio describe en detalle un sistema simple, robusto y de bajo costo para acondicionar agua de mar enriquecida en $\mathrm{CO}_{2}$ a través del burbujeo del agua de mar con mezclas de aire y $\mathrm{CO}_{2}$. El sistema mezcla aire con $\mathrm{CO}_{2}$ puro para producir dos niveles de $\mathrm{pCO}_{2}$ utilizando para ello controladores de flujo másico. Las mezclas aire- $\mathrm{CO}_{2}$ son enviadas a tambores con agua de mar y simultáneamente a un analizador de $\mathrm{CO}_{2}$ para verificar los niveles de $\mathrm{CO}_{2}$ en las mezclas aire- $\mathrm{CO}_{2}$ burbujeadas en los recipientes. Monitoreamos el pH y la alcalinidad por más de un año con el objeto de documentar el desempeño de largo plazo de este sistema emulando la futura química del carbono en agua de mar en un laboratorio costero. Concluimos que el desempeño del sistema es suficiente para mantener niveles $\mathrm{pCO}_{2}$ contrastantes (e.g., 397, 709, $1032 \mu \mathrm{atm}$ ) y relativamente constantes (el coeficiente de variación fue de $11 \%, 9 \%$ y $9 \%$, respectivamente) durante aproximadamente un año de monitoreo.

Key words: acidificación del océano, manipulación de la química de los carbonatos. 


\section{INTRODUCTION}

Carbon dioxide $\left(\mathrm{CO}_{2}\right)$ released due to human activities has caused a rise in the concentration of atmospheric $\mathrm{CO}_{2}$, and an increase in dissolved inorganic carbon content of oceanic surface waters. $\mathrm{CO}_{2}$ reacts with seawater reducing its $\mathrm{pH}$ (a phenomenon named Ocean Acidification (OA)) and carbonate ion concentration (Caldeira \& Wickett 2003; Orr et al. 2005; Raven et al. 2005). The carbonate ion reduction results in a decrease in the Aragonite (Ar) and Calcite $(\mathrm{Ca})$ saturation state of seawater (Orr et al. 2005). Therefore, it is predicted that the primary effect of OA will be the undersaturation of seawater in $\mathrm{Ar}$ in a vast part of the world's oceans, in particular high-latitude regions which have naturally low carbonate ion concentrations (Fabry et al. 2009; Orr et al. 2005).

The evidence that $\mathrm{OA}$ is occurring is now irrefutable (Orr et al. 2005). OA allows to fundamentally alter marine ecosystems in time frames that are essentially irreversible from the perspective of human societies (Raven et al. 2005). Understanding the impacts of OA in ocean ecosystems will likely be a major subject in marine science in the coming decades. In this context, developing $\mathrm{CO}_{2}$ systems that allows emulating the future conditions of an ocean with high $\mathrm{CO}_{2}$ levels is essential. An ideal manipulation of carbonate chemistry (i.e. $\mathrm{CO}_{2}$ system) should mimic exactly the changes to carbonate chemistry that will occur in years to come. During the last decade, experimental simulations of future marine carbonate chemistry have been conducted mainly in North America and Europe, to study the effect of OA on marine organisms (Fangue et al. 2010; Gattuso et al. 2010). A growing body of experimental evidence on OA effects is mainly derived from short-term experiments of typically less than 100 days duration (Kroeker et al. 2013), which normally corresponds to a small proportion of the life span of the respective model organisms. There is therefore a need to develop and test experimental facilities that can allow longer periods of experimentation (i.e. from several months to years) covering one or several life cycles of marine invertebrates, in order to know more about the physiological acclimation and the adaptation capacity of species to $\mathrm{OA}$.
Seawater chemistry can be manipulated in various ways in order to alter the carbonate system (Gattuso et al. 2010). Probably the most common carbonate system manipulation techniques are "aeration techniques" bubbling $\mathrm{CO}_{2}$-air mixtures or pure $\mathrm{CO}_{2}$ to reach a target $\mathrm{pH}$ or $\mathrm{pCO}_{2}$ level. Two major subgroups within these aeration techniques are (1) the " $\mathrm{pH}$ stat" and (2) the continuous bubbling with pre-mixed gases (Gattuso et al. 2010). The first is based on a feedback system through continuous monitoring of seawater $\mathrm{pH}$, and the intermittent injection of pure $\mathrm{CO}_{2}$ or $\mathrm{CO}_{2}$-free air to keep $\mathrm{pH}$ into a target range. The second is based on the continuous bubbling with an air$\mathrm{CO}_{2}$ mixture of a defined $\mathrm{pCO}_{2}$.

These two aeration techniques share a common weakness: they do not compensate for changes in $\mathrm{A}_{\mathrm{T}}$ resulting from precipitation and dissolution of $\mathrm{CaCO}_{3}$ or those changes resulting from evaporation. Furthermore the "pH-stat" is limited by inherent variability associated to the feedback system, while bubbling with premixed gases produces a less variable control on seawater $\mathrm{pCO}_{2}$. An accurate comparison between systems are beyond the scope of this paper, however there is clearly a wide variability in the setting and the performance of these systems, necessitating a detailed description of both methods and carbonate chemistry (Gattuso et al. 2010).

The carbonate chemistry experimental setup described here corresponds with the "aeration with pre-mixed gases" group. This system was implemented at Calfuco Marine Laboratory (http://www.ciencias.uach.cl/ unidades/calfuco/index.php), located in southern Chile $\left(40^{\circ} \mathrm{S}\right)$ near the city of Valdivia and under the influence of the Valdivia River. The coastal water supplied to the aquaria may therefore experience variations in salinity and other parameters associated with freshwater inputs, in addition to marine variations such as coastal upwelling and tidal cycles.

In this paper we will describe the first laboratory facility to study the consequences of the OA on marine invertebrates in Chile and South America. Moreover we discuss the longterm performance of this system (operative since late 2010) and others considerations in maintaining incubations at different $\mathrm{CO}_{2}$ levels for extended time periods (i.e. robustness and operational cost of the system). 


\section{METHODS}

The $\mathrm{pCO}_{2}$ generation system

This system manipulates carbon chemistry by changing Total Carbon $\left(\mathrm{C}_{\mathrm{T}}\right)$ at constant Total Alkalinity $\left(\mathrm{A}_{\mathrm{T}}\right)$, using the "Aeration to target $\mathrm{pCO}_{2}$ " technique (Gattuso et al.
2010). The $\mathrm{pCO}_{2}$ regulation system described here (Fig. 1) has been adapted to generate air- $\mathrm{CO}_{2}$ mixtures of $750 \mathrm{ppm}$ and $1200 \mathrm{ppm}$ in dry air. Those nominal levels correspond approximately with projected atmospheric levels for years 2079 and 2127 under RPC 8.5 scenario (Meinshausen et al. 2011; Riahi et al. 2007; Vuuren et al. 2011). Current (control) levels of $\mathrm{CO}_{2}$ (approx. 387-391

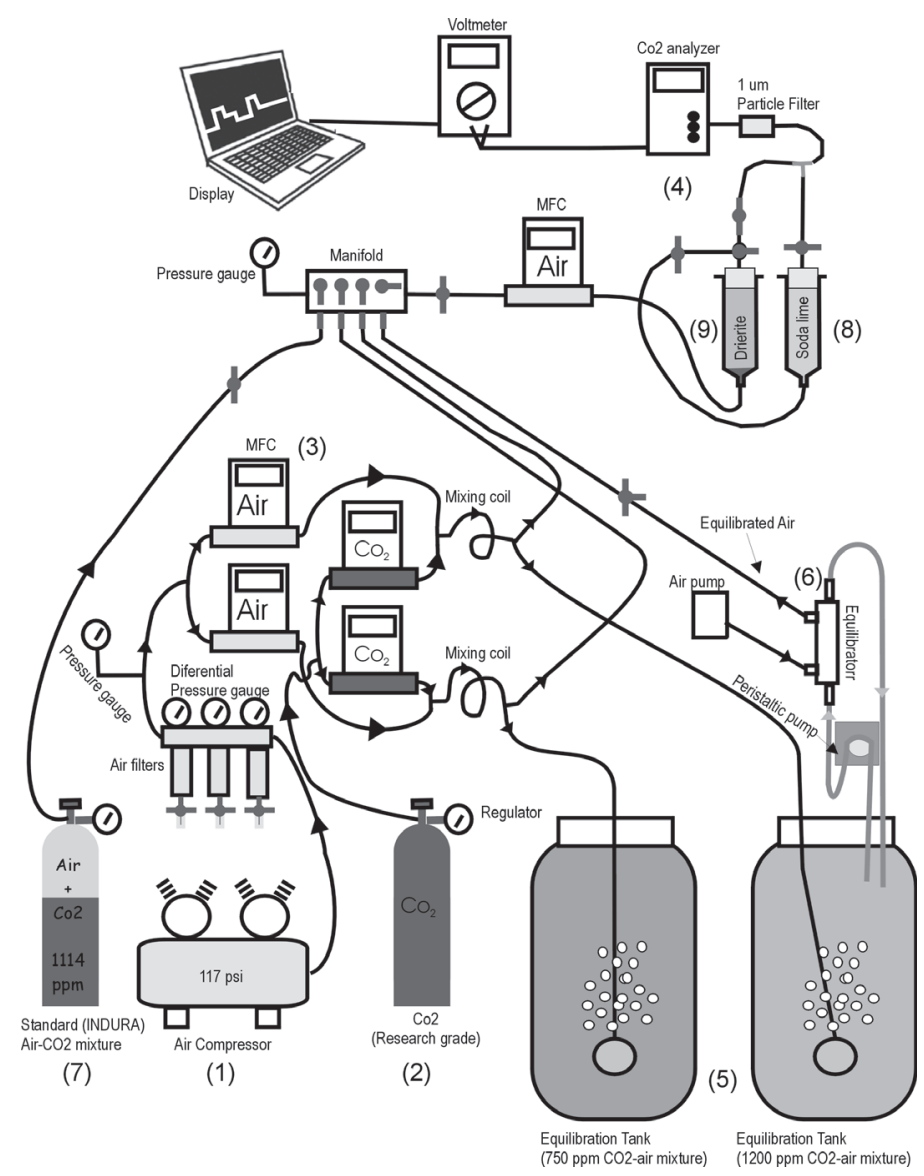

Fig. 1: Main characteristics of the Calfuco Marine Laboratory seawater- $\mathrm{CO}_{2}$ equilibration system. Compressed air (1) is blended with pure $\mathrm{CO}_{2}$ (2) using MFCs (3). The $\mathrm{CO}_{2}$-air mixture is split into two branches, one going to the $\mathrm{CO}_{2}$ analyser (4) to allow fine regulation of the MFCs, and the other to the seawater in the equilibration tanks (5). The $\mathrm{pCO}_{2}$ of the seawater in the mixing reservoirs can be monitored using a seawater-air equilibrator (6). The equilibrated air is pumped to $\mathrm{a} \mathrm{C}_{2}$ analyser, with analogue output. The voltage signal is displayed graphically to show the evolution of seawater equilibration with $\mathrm{CO}_{2}$. The $\mathrm{CO}_{2}$ analyser is calibrated with a standard $\mathrm{CO}_{2}$-air mixture (7) and with $\mathrm{CO}_{2}$-free air $\left(\mathrm{CO}_{2}\right.$ removed with soda lime, 8$)$. The gas entering the $\mathrm{CO}_{2}$ analyser is dried using a desiccant (9) and filtered (removing particles larger than $1 \mu \mathrm{m}$ ). The air- $\mathrm{CO}_{2}$ mixture is injected into the 2501 equilibration tanks or directly into the experimental treatments. Samples for discrete analysis of

$\mathrm{pH}$ and $\mathrm{A}_{\mathrm{T}}$ are collected periodically from the equilibration tanks to verify the functioning of the system.

Características principales del sistema de equilibración de agua marina con $\mathrm{CO}_{2}$ del laboratorio Marino de Calfuco. El Aire comprimido (1) se mezcla con $\mathrm{CO}_{2}$ puro (2) usando Controladores de Flujo Másico CFM (3). La mezcla $\mathrm{CO}_{2}$-aire se divide en dos ramas, una dirigida al analizador de $\mathrm{CO}_{2}$ (4) para permitir la regulación fina de los CFM, y la otra rama es dirigida al agua

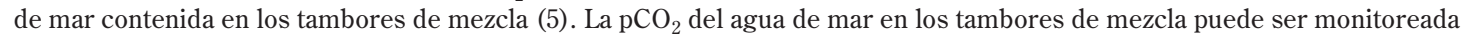
usando un equilibrador agua de mar-aire (6). El aire equilibrado es bombeado al analizador de $\mathrm{CO}_{2}$, el que cuenta con una salida analógica. La señal de voltaje se muestra gráficamente para mostrar la evolución de la equilibración con $\mathrm{CO}_{2}$. El analizador de $\mathrm{CO}_{2}$ es calibrado con una mezcla aire- $\mathrm{CO}_{2}$ estándar (7) y con aire libre de $\mathrm{CO}_{2}$ (donde el $\mathrm{CO}_{2}$ del aire fue removido con soda carbonatada, 8). El gas que ingresa al analizador de $\mathrm{CO}_{2}$ es secado usando un desecante (9) y filtrado (removiendo la partículas mayores de una micra). La mezcla aire- $\mathrm{CO}_{2}$ es inyectada en tambores de equilibración o directamente a los tratamientos de los experimentos. Periódicamente se recolectan muestras desde el tanque de equilibración para el análisis de $\mathrm{pH}$ y alcalinidad total de manera de verificar el funcionamiento del sistema. 
ppm for the 2011 and early 2012 period at the Southern Hemisphere; http://www.csiro.au) were obtained by the equilibration of seawater with atmospheric air. For the $750 \mathrm{ppm}$ and $1200 \mathrm{ppm}$ treatments, we blended dry air with pure $\mathrm{CO}_{2}$ to each target concentration using an air MFC (Aalborg, model GFC; http://www.aalborg.com) and a $\mathrm{CO}_{2} \mathrm{MFC}$ (Aalborg, model GFC). In total we used 4 MFC valves mounted on a board for horizontal gas flow. Dry and filtered air is generated by compressing atmospheric air (117 psi) using an oil-free, 4-piston air compressor (Schulz, model MSV12); the dry air passes through a particle filter rack (MTA; http://www.mta-it. com) to retain particles larger than $1 \mu \mathrm{m}$ before entering the air MFCs. Pressure in the air line is maintained at approximately $10 \mathrm{psi}$ using a standard regulator before entering the MFC valves. Similarly, pure $\mathrm{CO}_{2}$ (Research grade, INDURA; http://www.indura.cl) was regulated at $10 \mathrm{psi}$ using a single stage $\mathrm{CO}_{2}$ regulator. The air flow in the air MFCs was set at 5 litre min $^{-1}$ for both treatments, and the $\mathrm{CO}_{2}$ flows were set initially at 4.06 $\mathrm{ml} \mathrm{m^{-1 }}$ and $1.56 \mathrm{ml} \mathrm{min}^{-1}$, to theoretically (assuming that the $\mathrm{pCO}_{2}$ of the air used in the blend was already $388 \mathrm{ppm}$ of $\mathrm{CO}_{2}$ ) produce a $\mathrm{pCO}_{2}$ of $1200 \mathrm{ppm}$ and 750 ppm, respectively. Finally we manually adjusted the $\mathrm{CO}_{2}$ MFC flow until the required target $\mathrm{pCO}_{2}$ of the air- $\mathrm{CO}_{2}$ mixture was reached. The $\mathrm{pCO}_{2}$ of the air- $\mathrm{CO}_{2}$ mixture was continuously monitored using the system described below.

\section{The gas blend $\mathrm{pCO}_{2}$ monitoring system}

The $\mathrm{pCO}_{2}$ monitoring system was based on a $\mathrm{CO}_{2}$ analyser (Qubit system, model S151), primarily for measuring the $\mathrm{CO}_{2}$ content in the air- $\mathrm{CO}_{2}$ mixture. The $\mathrm{CO}_{2}$ analyser voltage output was displayed in a PC using a multimeter interface (RadioShack, model 22-812). Based on this monitoring methodology, we manually adjusted the $\mathrm{CO}_{2}$ MFCs to achieve the target $\mathrm{pCO}_{2}$, and we verified that the $\mathrm{pCO}_{2}$ remained constant. All air samples passing through the $\mathrm{CO}_{2}$ analyser were previously dried using a Drierite desiccant column (W. H. Hammond Drierite Co.; http://www.secure.drierite. com) and filtered (Millipore $1 \mu \mathrm{m}$ filter) (Fig. 1). The $\mathrm{CO}_{2}$ analyser was calibrated with air- $\mathrm{CO}_{2}$ mixture standards of $1,114 \mathrm{ppm}$ manufactured by INDURA (http://www.indura.cl), while zero was obtained by passing the air through a soda lime $\mathrm{CO}_{2}$-removal column (Fig. 1). The flow rate of the $\mathrm{CO}_{2}$-air mixture (samples and standard) entering the $\mathrm{CO}_{2}$ analyser was kept at approximately $150 \mathrm{ml} \mathrm{min}^{-1}$ using an Air-MFC (Aalborg).

\section{The seawater mixing reservoirs}

Once the experimental treatment gases are produced, each gas is mixed with $1 \mu \mathrm{m}$ filtered seawater (FSW hereafter) in a gas-mixing reservoir bucket. Each reservoir consists of a 250 litre food grade bucket (polyethylene $\mathrm{HADAD}$ plastics) into which the air- $\mathrm{CO}_{2}$ mixture is injected though a large aquarium grade air diffuser. The air- $\mathrm{CO}_{2}$ mixtures are injected at the bottom of the buckets at ca. 6-7 psi, using plastic tubing and an air-stone bubbler.

Since the air $-\mathrm{CO}_{2}$ mix is water undersaturated due to condensation in the air compression tank, evaporation of seawater causes an increment in salinity and total alkalinity. The magnitude of this increment is variable, and depends on the intensity of the bubbling relative to the volume of the seawater to be equilibrated, as well as other factors (e.g., temperature). We expect that maximum $\mathrm{A}_{\mathrm{T}}$ increments occur when a large dry air- $\mathrm{CO}_{2}$ mixture equilibrates with a small volume of water. In order to assess the magnitude of this effect, we measured the $\mathrm{A}_{\mathrm{T}}$ in one liter of filtered seawater before and after 24 hours of constant air- $\mathrm{CO}_{2}$ bubbling. In these experimental trials the total alkalinity concentration rose $8-12 \mathrm{mmol} \mathrm{l}^{-1} \mathrm{~d}^{-1}$ (an increment of ca. $0.4 \%$ of the initial $\mathrm{A}_{\mathrm{T}}$ ). Although this increment in alkalinity does not affect the final $\mathrm{pCO}_{2}$ of the equilibrated water, it does affect other aspects of carbon chemistry (e.g., changes in Omega, usually $<1 \%$ ). It is calculated that Omega will increase by $6 \%$ for each unit of salinity increment, and therefore we used two strategies to prevent or reduce the effect of increment in salinity and alkalinity: 1) frequent changing of the equilibrated water (e.g., total or partial daily replacement of the equilibrated water at $250 \mathrm{~L}$ container); 2) bubbling the mixture into the water to allow the air- $\mathrm{CO}_{2}$ mixture reach water saturation level, before injecting the air- $\mathrm{CO}_{2}$ mixture into the experimental reservoirs.

\section{Monitoring of $\mathrm{pCO}_{2}, \mathrm{pH}$ and $\mathrm{A}_{T}$ in equilibration reservoirs.}

The reservoir tanks were cleaned at regular intervals (approximately every 7 days) and the seawater was replaced with fresh FSW. Twelve hours after initiating the bubbling of the new seawater, we collected samples from the equilibration tanks and from the intertidal zone where the inlet of the seawater supply system is located, for analysis of the $\mathrm{pH}$ and $\mathrm{A}_{\mathrm{T}}$. The equilibrated seawater $\mathrm{pCO}_{2}$ may also be monitored by pumping the seawater to a gas exchange column or equilibrator (MiniModule Membrane Contactor; http://www.liqui-cel. com) and measuring the $\mathrm{pCO}_{2}$ of the equilibrated air. This last feature is particularly useful for determining the equilibration period after renewal of the seawater, i.e. when the $\mathrm{pCO}_{2}$-time relationship reaches a plateau (normally in the first $12 \mathrm{~h}$ ). However this latter procedure does not play any role in the functioning or calibration of the air- $\mathrm{CO}_{2}$ mixture generation system.

$\mathrm{pH}$ samples were collected in $50 \mathrm{~mL}$ syringes and immediately transferred to a close $25 \mathrm{~mL}$ cell, thermostatically controlled at $25.0^{\circ} \mathrm{C}$. The $\mathrm{pH}$ was measured at $25.0^{\circ} \mathrm{C}$ with a Metrohm $713 \mathrm{pH}$ meter (input resistance $>10^{13} \mathrm{Ohm}, 0.1 \mathrm{mV}$ sensitivity and nominal resolution $0.001 \mathrm{pH}$ units) and a glass combined double junction $\mathrm{Ag} / \mathrm{AgCl}$ electrode (Metrohm model 6.0219.100) calibrated with 8.089 Tris buffer (DOE 1994) at $25.0^{\circ} \mathrm{C} ; \mathrm{pH}$ values are reported on the total hydrogen ion scale (DOE 1994).

Seawater samples for $A_{T}$ were poisoned with $50 \mu \mathrm{L}$ of saturated $\mathrm{HgCl}_{2}$ solution and stored in $250 \mathrm{ml}$ polypropylene bottles in darkness at room temperature until analysis. $\mathrm{A}_{\mathrm{T}}$ was determined by potentiometric titration in an open cell with $0.05 \mathrm{M} \mathrm{HCl}$ (Merck Titrisol®) (Haraldsson et al. 1997). The accuracy was controlled against a certified reference material (CRM, supplied by Andrew Dickson, Scripps Institution of Oceanography, San Diego, USA). The correction factor was approximately 1.002 , corresponding to a difference of about $5 \mu \mathrm{mol} \mathrm{kg}{ }^{-1}$. Every sample was analysed with 2 or 3 replicates.

Omega $\mathrm{Ar}\left(\Omega_{\mathrm{Ar}}\right)$ and Omega $\mathrm{Ca}\left(\Omega_{\mathrm{Ca}}\right)$ were estimated from the pH-A pairs, in addition to temperature, salinity and pressure were obtained with a small CTD (Hydronaut). Carbonate system parameters calculations were performed using CO2SYS software (Lewis \&Wallace 1998) available on http://cdiac.ornl. gov/ftp/co2sys/. Seawater $\mathrm{pCO}_{2}$, Omega Aragonite and Omega Calcite were calculated using Mehrbach solubility constants (Mehrbach et al. 1973) refitted by Dickson and Millero (Dickson \& Millero 1987). The calculations were performed on a total hydrogen ion scale $\left(\mathrm{pH}_{\mathrm{T}}\right)$. For $\mathrm{KSO}_{4}$ we used the constant determined by Dickson (1990). 
Depending upon the experimental setting, the equilibrated seawater in the equilibration reservoirs was used in two distinct ways. In one type of experiments a special tubing system was used to allow seawater recirculation between the equilibration reservoirs and the rearing containers, the total volume of equilibrated water circulated through the rearing containers was approximately 10000 times the volume of the organisms. In other type of experiments the equilibrated seawater was used to fill the rearing containers and during the experimental rearing each container was connected with tubing to directly inject the required air- $\mathrm{CO}_{2}$ mixture. In this last case the volume of rearing containers was typically 500-1000 times the volume of the organism.

\section{Evaluation of the system to manipulate carbonate chemistry in the equilibration reservoirs.}

\section{Performance}

Aeration to achieve a target $\mathrm{CO}_{2}$ will change the amount and speciation of dissolved inorganic carbon in equilibration tanks, in turn modifying $\mathrm{pH}$ (Fig. 2A, B), $\mathrm{pCO}_{2}$ (Fig. 2E) and $\Omega_{\mathrm{Ar}}$ (Fig. $2 \mathrm{~F})$. The $\mathrm{pCO}_{2}$ of the $\mathrm{CO}_{2}$-enriched water
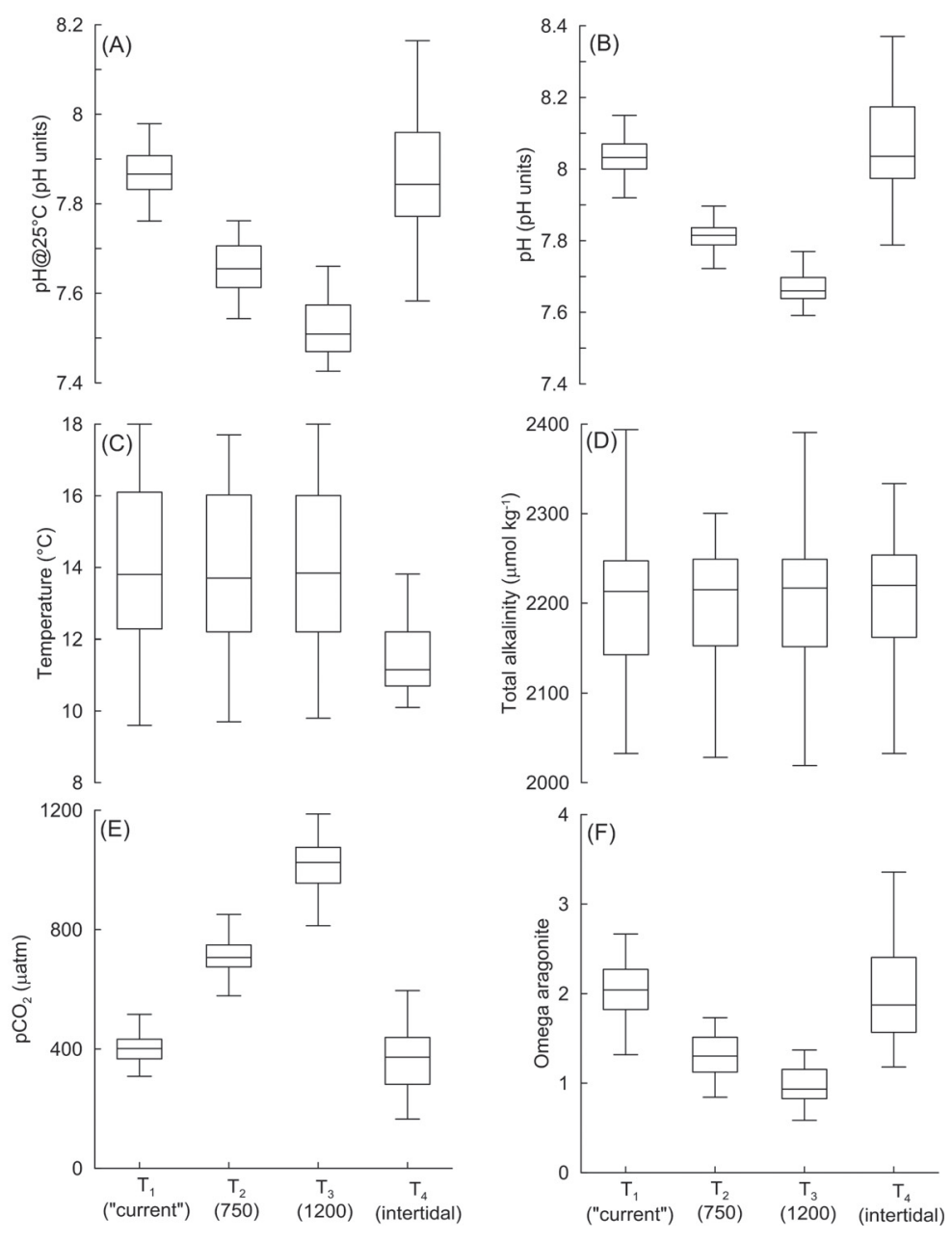

Fig. 2: Statistical parameters: $\mathrm{pH}$ measured at $25^{\circ} \mathrm{C}, \mathrm{pH}$ calculated at in situ temperature, temperature, total alkalinity, partial pressure of $\mathrm{CO}_{2}$ and Omega Aragonite, in the equilibration reservoirs and intertidal ( $\mathrm{T}_{1}$ for atmospheric treatment, $T_{2}$ for $750 \mathrm{ppm}$ treatment, $T_{3}$ for $1200 \mathrm{ppm}$ treatment, $\mathrm{T}_{4}$ for the intertidal site where the aquarium inlet is located) during 2011 and early 2012. The box plot indicates the smallest observation (sample minimum), lower quartile (Q1), median (Q2), upper quartile (Q3), and the largest observation (sample maximum).

Parámetros estadísticos: $\mathrm{pH}$ medido a $25^{\circ} \mathrm{C}, \mathrm{pH}$ calculado a la temperatura in situ, temperatura, alcalinidad total, presión parcial de $\mathrm{CO}_{2}$ y Omega aragonita, en los tanques de equilibración y en el intermareal (T1 es el tratamiento atmosférico, T2 es el tratamiento $750 \mathrm{ppm}$, T3 es el tratamiento de $1200 \mathrm{ppm}$, T4 es el intermareal donde se ubica la toma de agua del acuario) durante 2011 y comienzos del 2012. Los gráficos de caja indican la observación menor (el mínimo valor), primer cuartil (Q1), segundo cuartil ó mediana (Q2), tercer cuartil (Q3), y la mayor observación (el máximo valor). 
(inferred from $\mathrm{pH}$ and At measurements) was relatively low compared to the $\mathrm{pCO}_{2}$ of the air$\mathrm{CO}_{2}$ mixtures, particularly for the highest $\mathrm{CO}_{2}$ / air blend $(1200 \mu \mathrm{atm})$ which results in a mean seawater $\mathrm{pCO}_{2}$ of ca. $1032 \mu$ atm, i.e. $14 \%$ lower (see Fig. 2E).

The temperature and $\mathrm{A}_{\mathrm{T}}$ remained constant between treatments (Fig. 2C, D) but there was a conspicuous variation over the course of the year (Fig. 3B,C), caused by environmental factors such as variable influence of rivers, upwelling, annual temperature cycle, etc. The seawater $A_{T}$ at both the intertidal (inlet) and the equilibration reservoirs was positively correlated with salinity (Fig. 4). However events of low salinity water at the intertidal of Calfuco (e.g., < 30) were rare (Fig. 4).
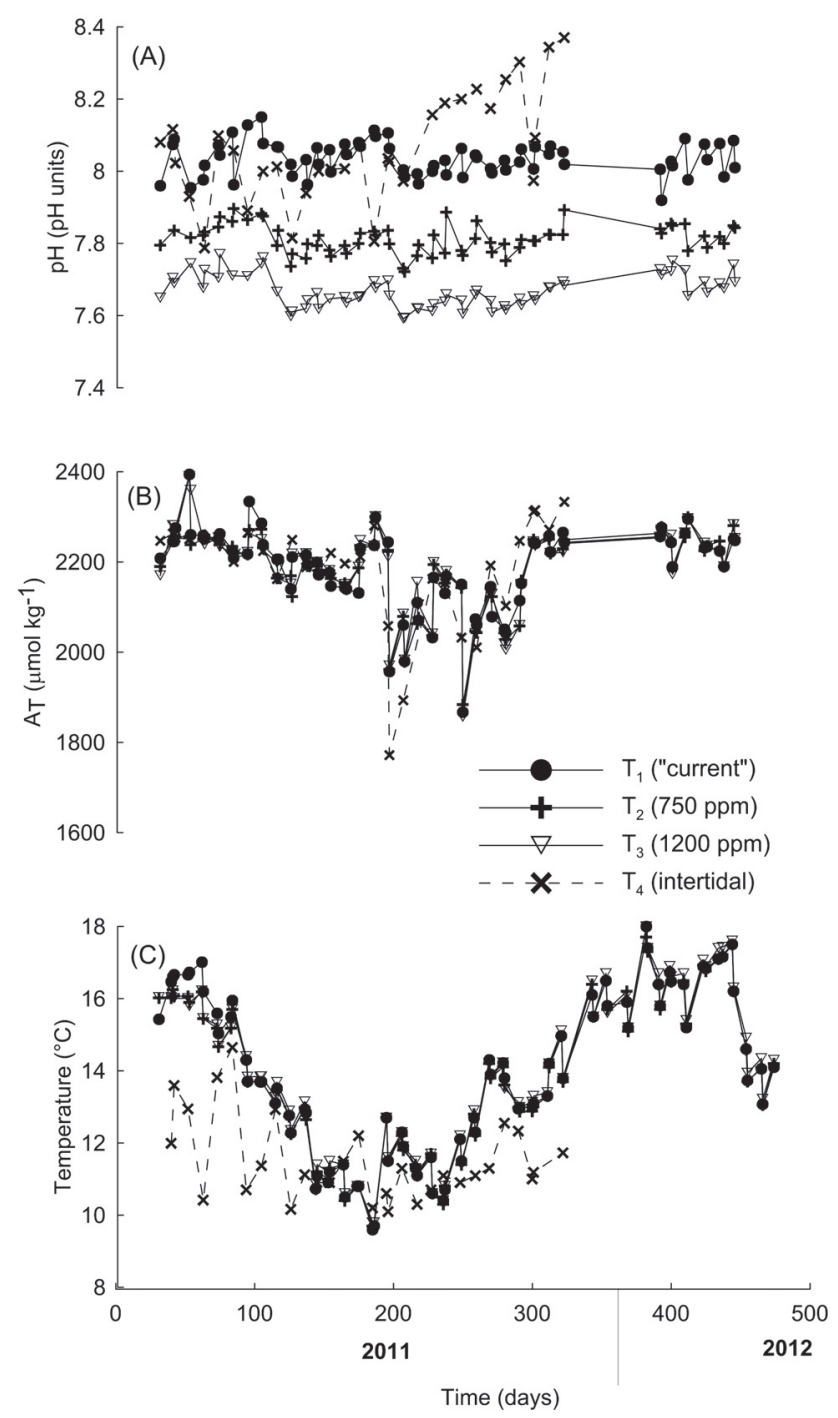

Fig. 3: Time series $\mathrm{pH}$ calculated at in situ temperature (i.e. the temperature in the equilibration tanks at the moment of sampling); $\mathrm{A}_{\mathrm{T}}$ and temperature in the equilibration reservoirs and intertidal $\left(\mathrm{T}_{1}\right.$ for Atmospheric treatment, $T_{2}$ for $750 \mathrm{ppm}$ treatment, $\mathrm{T}_{3}$ for $1200 \mathrm{ppm}$ treatment, $\mathrm{T}_{4}$ for the intertidal site where the aquarium inlet is located) during 2011 and early 2012.

Serie de tiempo de $\mathrm{pH}$ calculado a la temperatura in situ (i.e. la temperatura en los tanques de equilibración al momento del muestreo); $\mathrm{A}_{\mathrm{T}}$ y temperatura en los tanques de mezcla y en el intermareal (T1 es el tratamiento atmosférico, T2 es el tratamiento 750 ppm, T3 es el tratamiento de 1200 ppm, T4 es el intermareal donde se ubica la toma de agua del acuario) durante el 2011 y el comienzo del 2012. 


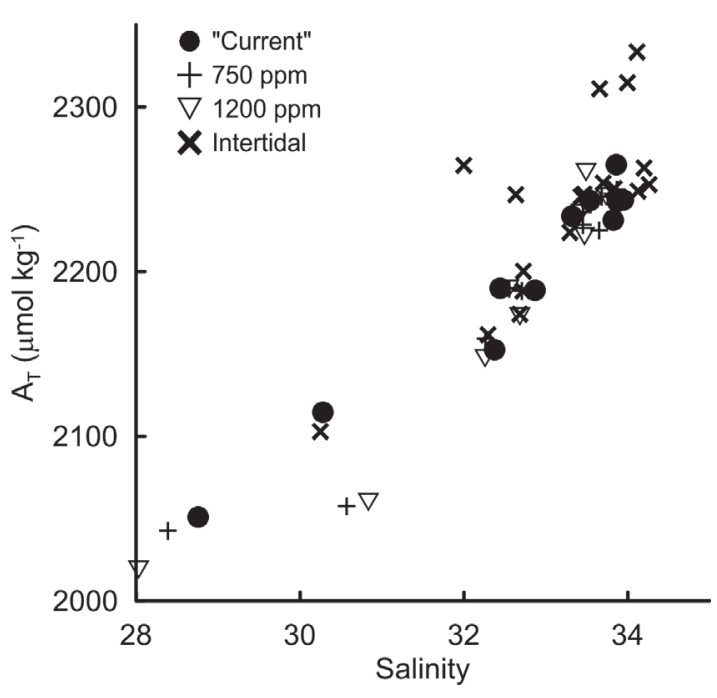

Fig. 4: $\mathrm{A}_{\mathrm{T}}$-Salinity relationship in the equilibration reservoirs and the intertidal $\left(\mathrm{T}_{1}\right.$ for Atmospheric treatment, $\mathrm{T}_{2}$ for $750 \mathrm{ppm}$ treatment, $\mathrm{T}_{3}$ for $1200 \mathrm{ppm}$ treatment, $\mathrm{T}_{4}$ for the intertidal site where the aquarium inlet is located) during 2011 and early 2012.

Relación entre $\mathrm{A}_{\mathrm{T}} \mathrm{y}$ salinidad en los tambores de equilibración y en el intermareal (T1 es el tratamiento atmosférico, T2 es el tratamiento 750 ppm, T3 es el tratamiento de 1200 ppm, T4 es el intermareal donde se ubica la toma de agua del acuario) durante el 2011 y el comienzo del 2012.

Environmental variations in temperature, $\mathrm{A}_{\mathrm{T}}$ and salinity explain most of the variability in $\mathrm{pH}$ and Aragonite $\left(\Omega_{\mathrm{Ar}}\right)$ in the $\mathrm{CO}_{2}$ enriched treatments. For example, based on the ranges of variation in temperature, salinity and $A_{T}$ measured in the atmospheric treatment seawater (i.e. $8.4{ }^{\circ} \mathrm{C}, 9$ and $526 \mu \mathrm{mol} \mathrm{kg}{ }^{-1}$ respectively), we calculated that the maximum fluctuation in $\mathrm{pH}$ and $\Omega_{\mathrm{Ar}}$ at constant $\mathrm{pCO}_{2}$ (i.e. at $\sim 380 \mu$ atm), should be $\sim 0.13 \mathrm{pH}$ units and $\sim 1.7$ respectively.

The lower variability of $\mathrm{pH}$ in the equilibration reservoirs when compared to the intertidal site (Fig. 2A) demonstrates the capacity of the system to manipulate carbonate parameters, even when critical variables (such as temperature) were not kept constant.

\section{Robustness}

The system requires little daily attention with the exception of: (1) draining the compressor reservoir (see Fig. 1) to remove condensed water, and (2) measuring $\mathrm{pH}$ and $\mathrm{A}_{\mathrm{T}}$ in the equilibration reservoirs. The $\mathrm{CO}_{2}$ mole fraction remained virtually constant for several weeks or even months, and so little adjustment of the MFCs was required. After more than a year of continuous functioning of this system we have not detected any malfunctions. Even during power failures the bubbling in the equilibration tanks restarted automatically when power was restored.

\section{Operational cost}

The operational costs of the experimental system are low (less than US\$ 2000 per year), consisting mainly in: (1) ultra pure $\mathrm{CO}_{2}$ (one $\mathrm{CO}_{2}$ cylinder per year), (2) air- $\mathrm{CO}_{2}$ standards (one every 1 or 2 years, depending on the frequency of IR calibration), and (3) maintenance or replacement of compressor pistons (probably after 1-2 years). The most significant cost is related to accurate monitoring of $\mathrm{pH}$ and $\mathrm{A}_{\mathrm{T}}$, including reagents, buffers, electrodes and reference seawater material (ca. US\$ 5000 per year).

\section{DISSCUSION}

The "aeration to target $\mathrm{pCO}_{2}$ " system described here was sufficient to maintain different $\mathrm{pH}$, $\mathrm{pCO}_{2}$ and $\mathrm{CaCO}_{3}$ saturation states in the treatments year round. However the air- $\mathrm{CO}_{2}$ mixtures $\left(\mathrm{pCO}_{2}\right.$ of $750 \mu \mathrm{atm}$ and $\left.1200 \mu \mathrm{atm}\right)$ injected into the equilibration tanks produce $\mathrm{CO}_{2}$-enriched seawater with a lower $\mathrm{pCO}_{2}(6$ $\%$ and $14 \%$ lower, respectively; see Fig. 2E). We estimate that the dilution effect of water moisture on seawater $\mathrm{pCO}_{2}$ can explain $1-2 \%$ of the $\mathrm{pCO}_{2}$ reduction from the originally dry air-CO2 mixture. Seawater fully equilibrated with a dry air- $\mathrm{CO}_{2}$ mixture with a $\mathrm{pCO}_{2}=1200$ $\mu \mathrm{atm}$ should produce a maximum seawater $\mathrm{pCO}_{2}$ of $1176 \mu \mathrm{atm}$ at $18{ }^{\circ} \mathrm{C}$. The rest of this discrepancy can be attributed to the incapacity of this system to fully equilibrate seawater at high $\mathrm{pCO}_{2}$ levels in a period of $12 \mathrm{~h}$. Seawater $\mathrm{pCO}_{2}$ increment slows down as seawater $\mathrm{pCO}_{2}$ approaches to the target $\mathrm{pCO}_{2}$ levels, in asymptotic fashion, requiring longer equilibrations periods that the one used here (12 hours). However, in spite of the discrepancies discussed above, this system had the capacity to produce significantly different $\mathrm{CO}_{2}$ levels in seawater (Fig. 2E) with 
a relatively low variability $(\mathrm{CV}=9 \%)$. This overall variability includes the effect of the natural variability in salinity, alkalinity and temperature, as well as the bias in the $\mathrm{pH}$ and $\mathrm{A}_{\mathrm{T}}$ measurements, and uncertainties in the $\mathrm{pCO}_{2}$ calculation. The error of $\mathrm{A}_{\mathrm{T}}$ analysis was constrained using reference material. The $\mathrm{pH}$ error was calculated to be lower than 0.006-0.009 $\mathrm{pH}$ units (Torres et al. 1999) however in the few occasions when salinity dropped below 30, additional bias, associated with larger differences in the liquid junction potential between the buffer and the sample, are expected to become significant (Wedborg et al. 2007). Tests on the same sample using TRIS buffer, at salinity 35 and 25, show minor discrepancies (<0.005 pH units); we expect that even in this particular example (salinity range between 28-30) the $\mathrm{pH}$ error does not exceed $0.01 \mathrm{pH}$ units. If we consider that maximum uncertainties of $\mathrm{pH}$ and alkalinity are in the order $0.01 \mathrm{pH}$ units and ca. 9 in alkalinity, we expect a total error of ca.10 $\mu \mathrm{atm}$ for our $\mathrm{pCO}_{2}$ estimations (Torres et al. 1999), which in turn corresponds with a small percentage of the $\mathrm{pCO}_{2}$ of the $\mathrm{CO}_{2}$-enriched treatments (ca. $1 \%$ ). Thus most of the overall variability reported here arises because of changes in temperature, salinity and alkalinity over time. Despite less than full control over these parameters, the system was sufficient for long term experimentation at contrasting $\mathrm{pCO}_{2}$ (Fig. 2E), pH (Fig. 2A) and Omega Ar (Fig. 2F) levels.

The natural variability of $\mathrm{pH}$ and $\mathrm{pCO}_{2}$ along the coast of Chile (Torres et al. 2011; Torres et al. 1999) is extreme when compared to other geographic areas (e.g., Tropical waters (Astor et al. 2005)), hence the fluctuation in carbonate system parameters in the different treatments shown here is not unusual for marine life in this region. Moreover a fully constant chemostat (for $\mathrm{pH}$ or $\Omega_{\mathrm{Ar}}$ ) might be considered unrealistic for simulating high- $\mathrm{CO}_{2}$ scenarios to which coastal organisms in Eastern Boundary Current systems may be exposed. Therefore we conclude that the performance of the system described here is adequate to simulate high$\mathrm{CO}_{2}$ scenarios for Chilean coastal waters under laboratory conditions.

The robustness of this system makes it suitable for short and long-term experiments (months to years), necessary to adequately investigate the consequences of $\mathrm{OA}$ on marine invertebrates. Using the system described here we have been able to rear egg-capsules of Concholepas concholepas (Bruguière, 1789) during almost their entire developing period until hatching (i.e., 30-60 days of rearing), and small juveniles of the same species originating from competent larvae collected in the field (i.e. 1 to 2 years of rearing, (Manríquez et al. 2013)). Other species such as the mitilid Mytilus chilensis (Hupé, 1854) and the intertidal snail Acanthina monodon (Pallas, 1774) have also been reared in this system (Navarro et al. 2013). These experiments carried out so far, have shown significant effects of OA on the studied species, both positive and negative (e.g., Navarro et al. 2013). This highlights that the system is well suited for long-term experiments investigating the consequences of $\mathrm{OA}$ on the performance of early ontogenetic stages of marine invertebrate species. Finally, it is important to highlight that the relatively lowcost maintenance (ca. US\$ 20 per day) makes this system economically feasible for a wide range of marine laboratory facilities.

ACKNOWLEDGEMENTS: We thank Constanza Maureira, Nolasca Valdes, Maria Elisa Jara, Emilio Alarcon and Tania Optiz for their assistance in monitoring the carbonate system parameters and in the maintenance of the system. This work was supported by Programa de Investigación Asociativa, PIA-CONICYT-CHILE (Grant Anillos ACT-132 to RT, PHM, NAL, CV, MAL \& JMN), Project Fondecyt Grant 1090624 (to NL CV, MAL, RT and PHM) and Project Fondecyt Grant 11110407 (CD). We thank two anonymous reviewers for helping us with their valuable comments and suggestions.

\section{LITERATURE CITED}

ASTOR YM, MI SCRANTON, F MULLER-KARGER, R BOHRER \& J GARCÍA (2005) fCO2 variability at the CARIACO tropical coastal upwelling time series station. Marine Chemistry 97: 245-261.

CALDEIRA K \& ME WICKETT (2003) Anthropogenic carbon and ocean pH. Nature 425: 365.

DICKSON AG \& FJ MILLERO (1987) A comparison of the equilibrium constants for the dissociation of carbonic acid in seawater media. Deep Sea Research 34: 1733-1743.

DOE (1994) Handbook of methods for the analysis of the various parameters of the carbon dioxide system in sea water; version 2.1. U. S. Department of Energy, (on line) http://cdiac.ornl.gov/oceans/ DOE_94.pdf (accessed 29 August, 2013).

FABRY VJ, JB MCCLINTOCK, JT MATHIS \& JM GREBMEIER (2009) Ocean acidification at high latitudes: the bellwether. Oceanography 22: 160171. 
FANGUE NA, MJ O'DONNELL, MA SEWELL, PG MATSON, AC MACPHERSON, et al. (2010) A laboratory-based, experimental system for the study of ocean acidification effects on marine invertebrate larvae. Limnology Oceanography Methods 8: 441-452.

GATTUSO J-P, K GAO, K LEE, B ROST \& KG SCHULZ (2010) Approaches and tools to manipulate the carbonate chemistry. In: U Riebesell, VJ Fabry, L Hansson \& J-P Gattuso (eds) Guide to best practices for ocean acidification research and data reporting: 41-52. Publications Office of the European Union, Luxembourg.

HARALDSSON C, LG ANDERSON, M HASSELLÖV, S HULTH \& K OLSSON (1997) Rapid, highprecision potentiometric titration of alkalinity in ocean and sediment pore waters. Deep Sea Research Part I 44: 2031-2044.

KROEKER KJ, RL KORDAS, R CRIM, IE HENDRIKS, L RAMAJO, et al. (2013) Impacts of ocean acidification on marine organisms: quantifying sensitivities and interaction with warming. Global Change Biology 19: 1884-1896.

LEWIS E \& D WALLACE (1998) Program developed for $\mathrm{CO} 2$ system calculations. Carbon Dioxide Information Analysis Center, (on line) URL: http://cdiac.ornl.gov/oceans/co2rprt.html (accessed 29 August, 2013).

MANRIQUEZ PH, ME JARA, ML MARDONES, JM NAVARRO, R TORRES, et al. (2013) Ocean acidification disrupts prey responses to predator cues but not net prey shell growth in Concholepas concholepas (loco). PLoS ONE 8: e68643.

MEHRBACH C, CH CULBERSON, JE HAWLEY \& RN PYTKOWICZ (1973) Measurement of the apparent dissociation constants of carbonic acid in seawater at atmospheric pressure. Limnology and Oceanography 18: 897-907.

MEINSHAUSEN M, SJ SMITH, K CALVIN, JS DANIEL, MLT KAINUMA, et al. (2011) The RCP greenhouse gas concentrations and their extensions from 1765 to 2300. Climatic Change 109: 213-241.

NAVARRO JM, R TORRES, K ACUÑA, C DUARTE, PH MANRIQUEZ, et al. (2013) Impact of mediumterm exposure to elevated pCO2 levels on the physiological energetics of the mussel Mytilus chilensis. Chemosphere 90: 1242-1248.

ORR JC, VJ FABRY, O AUMONT, L BOPP, SC DONEY, et al. (2005) Anthropogenic ocean acidification over the twenty-first century and its impact on calcifying organisms. Nature 437: 681-686.

RAVEN J, K CALDEIRA, H ELDERFIELD, O HOEGHGULDBERG, P LISS, et al. (2005) Ocean acidification due to increasing atmospheric carbon dioxide. Policy document $12 / 05$, The Royal Society, London.

RIAHI K, A GRUBLER \& N NEBOJSA (2007) Scenarios of long-term socio-econiomic and environmental development under climate stabilization. Technological Forecasting \& Social Change 74: 887-935.

TORRES R, S PANTOJA, N HARADA, HE GONZÁLEZ, G DANERI, et al. (2011) Air-sea CO2 fluxes along the coast of Chile: From $\mathrm{CO} 2$ outgassing in central northern upwelling waters to $\mathrm{CO} 2$ uptake in southern Patagonian fjords. Journal of Geophysical Research 116: C09006.

TORRES R, D TURNER, N SILVA \& J RUTTLANT (1999) High short-term variability of $\mathrm{CO} 2$ fluxes during an upwelling event off the Chilean coast at 30 S. Deep Sea Research Part I 46: 1161-1179.

VUUREN DP, J EDMONDS, M KAINUMA, K RIAHI, A THOMSON, et al. (2011) The representative concentration pathways: an overview. Climatic Change 109: 5-31.

WEDBORG M, DR TURNER, LG ANDERSON \& D DYRSSEN (2007) Determination of pH. In: K Grasshoff, K Kremling \& M Ehrhardt (eds) Methods of seawater analysis: 109-125. Third Edition, Wiley-VCH Verlag GmbH, Weinheim. 
